\title{
ELIANE CHIRON
}

\author{
Íntima mutação da pintura no \\ vídeo digital \\ Tradução: Sandra Rey
}

\section{RESUMO}

Desde que realizo vídeos digitais, ainda posso ser considerada pintora? O vídeo me faz, a cada vez, retornar à pintura e é assombrado pelas frases: as cores "fazem queimar meu cérebro" (Malevich) e se vêm "como cicatriz sobre um rosto" (Cenino Cennini).

No vídeo Les Nageuses (20I I ), como a descrição de piscina por Merleau-Ponty, "modelo do que busca o artista", se encarna nesse vídeo? Como o íntimo na arte, que segundo Daniel Arasse surgiu no quadro do Ranascimento, se metamorfoseou em Les Nageuses? As referências históricas serão necessárias para compreender que pintar supõem um contato íntimo com a matéria pictórica, mesmo que essa matéria seja produzida em código, sem medo de aí se perder.

PALAVRAS-CHAVE

Contemporâneo. Cor cicatriz. Íntimo.

Mutabilidade.Vídeo digital. 


\section{ÍNTIMA MUTAÇÃO DA PINTURA NO VÍDEO DIGITAL}

Quando eu digo cor, isso significa de toda matéria pictórica.'

\section{Cor cicatriz}

Não aprendi a pintar na Escola de Belas Artes. Malevich também não, tampouco Picasso. Cézanne não foi aprovado no processo de seleção. Outra época? Sem dúvidas mas, enfim. Picasso aprendeu todas as técnicas de arte (techné) com seu pai, diretor da Escola de Artes e Ofícios em La Coruña, na Espanha; Malevich preferiu, como todos os jovens artistas de sua época na Rússia, estudar em uma escola de Artes Aplicadas. Sabe-se que ele inventou o seu Quadrado Negro para a peça de teatro Victoire sur le soleil, na efervescência de intercâmbios entre teatro, poesia, música e pintura, num verão à beira do mar Báltico. Somente ele foi capaz de operar a transferência profética da cortina do palco em pintura, que nomeou de "suprematista". E revoluciona a pintura. Em minha mente algumas frases estão marcados a ferro quente: As cores são "cheias de exigências, elas fazem meu cérebro ferver” (Malevich), "Eu não procuro, eu encontro" (Picasso), e essa de Braque, menos conhecida, "o que me salvou é que eu nunca soube o que eu queria", ou então "É preciso que a tela apague a idéia"

LYOTARD, J. F. L'inhumain. Causeries sur le temps, Paris, Galilée, 1988, p. 163.

BAZAINE, J. Le temps de la peinture (1938-1989), Paris, Aubier, 1990, p. 71 .

CENNINI, Cennino. Le livre de l'art ou traité de la peinture (entre 1390 et 1437), descoberto pela primeira vez por chevallier Tambroni, trad. V. Mottez (1858), nouv. éd. augm. Paris, F. de Nobele, 1978, p. 32. ou ainda "a realidade, não é isso, é nisso". Isso quer dizer que a linguagem sempre foi para mim, como para os alquimistas em outras épocas, a via de acesso à pintura enquanto prática, esse conceito de prática significando exatamente a passagem através da matéria. Que matéria? Cennino Cennini nos dá uma idéia, no início do Livre de l'art, contando sobre seu encontro com a cor. Foi, depois de uma longa viagem com seu pai, em uma montanha distante, no chão de uma caverna onde "veios coloridos", incluindo o branco, "se percebia como se fosse uma cicatriz num rosto3". Cena com a qual Louise Bourgeois vai brincar nas suas cabeças em tapeçarias costuradas como em O Golem, dizendo (e lhe damos crédito) que ela "escolheu a arte ao invés de vida." Nestas cabeças auto-retratos, ninguém dúvida, as cicatrizes-costuras são suas, signos de arte nela mesma. Os gestos lembram o ateliê familiar de restauro de tapeçarias mas ela reencena aí seu encontro com a cor, lavada no rio ao final do jardim, em Choisy e no departamento de Creuse. Conhecida como escultora, ela pode ser considerada uma pintora, nestas cabeças? 
Já que abandonei os pincéis, que não cubro mais de pintura um suporte, trabalho com imagens no computador e realizo vídeos digitais antes de ter aprendido a técnica (mas eu sei o significa pintar e desenhar), eu ainda faço pintura? Mesmo que não procure pintar com o vídeo, sou obrigada a constatar, à cada vez, que o que faço é voltar à pintura; percebo que se opera uma transferência no vídeo e, no final, sem ter procurado, é a pintura que encontro. E penso nos últimos Ticianos, nos últimos Goyas da Casa del Sordo, onde a tinta é jogada em respingo ao desprezo da matéria, reinventando os primeiros gestos da arte.

Por um lado, então, a linguagem, as palavras que nomeiam o mundo exterior, transfigurada pela arte, se encarnando nela (cujo fogo não pára de arder) e, por outro "as veias de cores" de uma caverna na montanha, como "cicatrizes num rosto", e não em outro lugar, a presença sob o "olhar desarmado", ou seja, o mundo interior que se encarnou. Nesta cena, o "branco" dá acesso à cor, à carne e ao sangue matérias da arte da pintura com tudo o que se desprende do corpo, e tudo o que, na escuridão telúrica, no fundo dos oceanos, se metamorfoseia. Magma viscoso que se esmaga em dobras profundas e fraturas gigantescas, escorre e jorra a cada segundo.

A hipótese é esta: o meu vídeo digital As Nadadoras (6'50, 20 I 0, 2'2I , 201 I ), que se pode projetar ou exibir em uma tela de TV, poderia ser chamado de pintura.Vamos verificar essa hipótese através da definição de pintura de W. Benjamin ${ }^{5}$, definição especificada pela "mancha" que emerge tornando-se "marca", e as observações de Goethe sobre a cor viva. Como a descrição da piscina segundo Merleau-Ponty,"modelo do que os pintores buscam conquistar", se encarna neste vídeo? Como o íntimo na arte, que de acordo com Daniel Arasse apareceu no quadro do Renascimento ${ }^{6}$, se transferiu para As Nadadoras? Será que, no final, saberemos um pouco mais sobre o ato de pintar?

\section{A marca e a mancha, paradigmas da pintura}

Para Walter Benjamin a "marca" caracteriza o "meio" da cor cujo modelo é o enrubescer do rosto pela pudor, ou os estigmas de Cristo, marca-cicatriz que surge numa pessoa e possui uma dimensão temporal. A cor é também "mancha" que aparece e desaparece sobre o que é vivo, mas também marca, quando se pendura temporariamente um quadro na parede 7 . É o paradigma da pintura, onde "a marca é sempre absoluta, e sua aparição nunca se iguala". Na verdade a cor se mostra agora e sempre "específica, característica, significativa, seu nascimento e sua determinação são uma só coisa”. Assim, a cor diz respeito ao aparecer, não à aparência. $\bigcirc$ que descarta imediatamente a questão da mimesis. "Não há viço originário, mas tantos estados de viço quanto [...] de olhares desarmados”, precisará Lyotard. O vídeo As Nadadoras pela sua rapidez, sua brevidade propositada e sua montagem em loop é,
4

LYOTARD, J. F. op. cit., p. 163.

BENJAMIN, Walter. Peinture et graphisme. De la peinture ou le signe et la marque (Surkamp Verlag, Frankfurt am Main, 1977), trad. P. Pénisson, La part de l'œil, dossier Le dessin, 6, 1990, pp. 13-15. Écrits français, prés. et intr. J.M. Monnoyer, Paris, Gallimard, 1991, p. 189-192.

ARASSE, D. Le sujet dans le tableau. Essais d'iconographie analytique (1997), Paris, Flammarion, 4è édition 2010.

BENJAMIN, Walter. Op. cit., 
à cada segundo, aparição da cor que desaparece. Assim, no final, quando a última nadadora se asfixia em uma piscina de pixels pela equivalência da seleção de cores e da combinação das seqüências, isso corresponde ao que Roman Jakobson chama de "função poética", equivalência entre a seleção de cores e a combinação das seqüências. Surpreendente poder da cor, que corta o olhar em dois... Uma cor mutante, como um olhar que se altera, onde visar contém a ideia do olhar ofensivo e mortal. Como se os nossos olhos assassinassem a nadadora. No vídeo, as duas nadadoras que se sucedem são como alguns peixes de águas quentes que, pouco antes de sua morte, se tornam cintilantes. Entre o nascimento e a morte, a cor acompanha as transformações dos seres vivos e da reprodução sexual. $O$ sexo de um organismo é determinado pelas cromossomas $\mathrm{X}$ ouY no núcleo das células, particularmente visíveis na fase de divisão.

Goethe observa que "nos insetos cujo desenvolvimento comporta uma metamorfose completa, principalmente os besouros e as borboletas, a potencia das cores se revela da maneira mais notável em ligação com uma organização regular"8. Insetos, insectus, têm um corpo seccionado, não somente na fase adulta, mas também na estrutura de sua metamorfose. Da larva ao besouro adulto, cujas asas comportam, por vezes, uma mancha arredondada cujo centro é de uma cor diferente da circunferência, - estranhas culminações do processo cromático - a cor está sempre lá. Alojada nas entranhas, aninhada na crisálida, ele deve romper uma carapaça para aparecer, frágil e efêmera, sobre as asas intocáveis da borboleta. Assim, o pigmento não adere à membrana reticulada da asa quando a tocamos e a tinta se cola nos dedos, é pura superfície se desprendendo de seu suporte; a cor é o lugar das metamorfoses e transmutações. $O$ filtro de onde verte (colare) um tempo reversível. No seio da cor culmina o quiasma entre a superfície (as asas) e a profundidade (os ovos). A reversibilidade entre superfície e profundidade também ocorre no bater de asas das borboletas, na intermitência do cintilar das asas, onde vacila a cor. Nessa falha onde a cor se faz e se desfaz, se realiza a essência do olhar, traço evanescente e puntiforme, imperceptível cor das coisas, pintadas com reflexos instáveis. As coisas nos dizem respeito ao sabor dos reflexos que as tocam e, até mesmo sobre o aço, pela graça de um simples sopro exalando seu nevoeiro, uma onda de cores fugidias, arrebatadoras, se desprende. Que houvesse essa fugacidade nas Nadadoras foi a minha obsessão. Incansavelmente, eu precisava "reduzir, reduzir", como Duchamp queria. Em suma, fazer um vídeo "rápido", que tivesse a velocidade dos comerciais televisivos de hoje.

Para Benjamin, a pintura não tem fundo, o que a torna específica é uma mancha que se desprende de um fundo. Este fundo do qual emerge, é o dilúvio; o flutuar da pintura diante de seu suporte causa a ilusão de emergir do dilúvio. Quando a pintura adota os tons terra, por exemplo, em Tables de Dubuffet ou nos quadros de Eugene Leroy, opera, sem dúvidas, o retorno à origem telúrica das cores, à esta dimensionalidade 
onde ocorre a deflagração do ser regressando ao abismo que o artista ressente mais do que qualquer outro. Profundidade da qual um mergulhador deve retornar, disse Valéry. Profundidade que Dubuffet constela com asas de borboleta. Uma vez que o artista não é uma borboleta com cores vibrantes, onde deveria ele ir buscar sua cor, desde sempre? Lacan nos sussura ao pé da orelha': nos resíduos, na viscosidade do material desintegrado, esmagado, dissolvido e oxidado, digerido, apodrecidas na água, cozidas pelo calor, o fogo ou ao sol. Na lama e nas vísceras. É lá onde, desde os começos, a cor se faz. São as cores nativas de Duchamp, a cor do chocolate que o celibatário mói, ele mesmo... essas são as cores-matérias de Les Nageuses.

Porque se sobressai, especialmente na pintura, a cor faz esquecer o sem fundo primordial de onde vem: do abismo, por definição, sem fundo. O vermelho no início de Les Nageuses se assemelha à última pincelada em Frenhofer:para o pintor, não existe nenhum grau abaixo do afloramento à superfície, como na garganta dos afogados... Se, nas palavras de Roger de Piles, a cor é uma maquiagem, isso só pode ser na expressão: corar subitamente*, é o pharmakon com o qual se maquia os cadáveres, dando a ilusão de vida. Ela deve, portanto, dar a impressão de ter "brotado" no suporte, de ser uma zôgraphia, uma pintura viva. Klee multiplica as camadas de fundo em suas pinturas e as cores de Poussin parecem emergir das trevas para aí retornar. $O$ nascimento de vida em equivalência com a morte, talvez seja esse também o escândalo de Olympia: a cor cadavérica do corpo de Victorine Meurent, que diz da possível putrefação da carne, da origem repugnante das cores, da morte sobre a vida, e que, decapitada pela fita ao redor do pescoço, olha-nos diretamente nos olhos. As cores de Les Nageuses, emergindo das trevas, nos olham de suas profundezas.

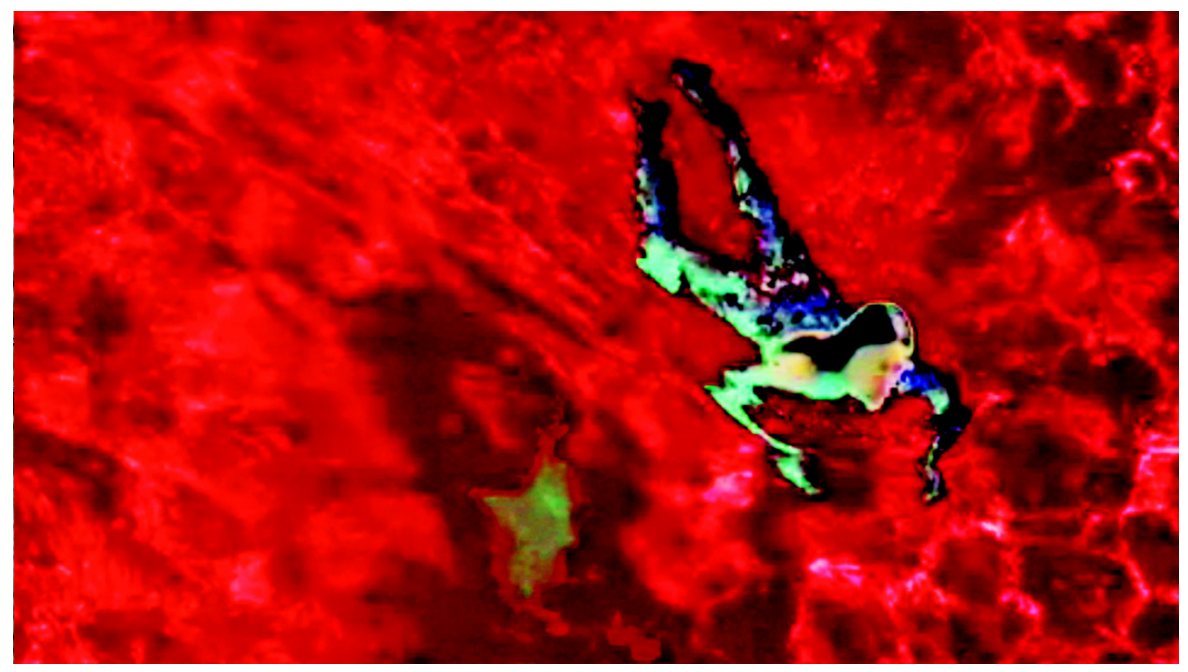

9

LACAN, J. Le séminaire. Livre XI. Les quatre concepts fondamentaux de la psychanalyse (1964), Paris, Seuil, 1973, p. 107.

No original: la couleur est un fard, ce ne peut être selon l'expression :"piquer un fard". A autora faz um jogo entre a palavra "fard", maquiagem, disfarce, e a expressão "piquer un fard" que significar corar, enrubescer subitamente, ficar vermelho como um pimentão. N.T.

Éliane Chiron.

Les Nageuses I, vídeo digital, 2' 24, 201 I. 
Esta cor-matéria que os antigos já conheciam e incorporavam na arquitetura, em um gesto arcaico desafiando as medidas e os cálculos de especialistas, era inassimilável, irrupção do telúrico nos frontões dos templos, animalidade no labor intelectual. Ruptura que nos coloca face à face ao ser selvagem, este tecido comum do qual somos feitos, que se interpõe diante de nós no mundo vertical. Para Benjamin, a pintura é vertical, é o que do mundo se levanta e olha para a luz. Ela quer esquecer suas origens telúricas, que o desenho, permanecendo horizontal, faz lembrar que está mais perto do abismo. Seria a piscina, esse abismo?

\section{Filmar na piscina.A irradiação visível}

A partir da janela do meu quarto de hotel em Manama, capital do Bahrein, onde estava de passagem para uma exposição individual em março de 2008, filmei duas nadadoras mergulhando na piscina. Sabemos que um trabalho deve retraçar a totalidade da história do seu objeto (nesse caso, a piscina e duas nadadoras). Bacia para purificação nos rituais cristãos, a qual o peixe (piscis) é o emblema, a piscina é, na liturgia,"um pequeno tanque destinado a receber a água que foi usado para batismos, e à purificação de objetos sagrados" 10 ."Grande bacia de natação desde século XVI, agora um sinal de elevação social, a piscina é também bacia de desativação de um reator de usina nuclear. Esta constelação de significados da palavra piscina, suas mutações do religioso ao social e ao científico, e à energia nuclear onde a piscina desativa e purifica a energia atômica de seu possível perigo de morte atravessa,com uma palavra, a história das substâncias e instala um conluio entre o sagrado, o átomo e o pixel. Segundo Merleau-Ponty, “a água em si mesma, potência aquosa, elemento viscoso e cintilante, não posso dizer que esteja no espaço: não está em outro lugar, mas não na piscina. Ela a habita, aí se materializa, não está contida, e se eu olhar para os ciprestes onde se projeta sua rede de reflexos, eu não posso negar que a água os visita também, ou, pelo menos, envia aí sua essência ativa e viva. É esta animação interna, a irradiação do visível que o pintor procura sob os nomes de profundidade, de espaço, de cor" 'I. Essa "animação interna", essa "irradiação do visível” ecoa na mente com todos os sentidos da palavra piscina. Assim, na Villa Amalia (2009) a heroína, Éliane, compositora musical, sufoca em sua própria vida. Numa piscina urbana, ela usa óculos de mergulho que a fazem parecer com um peixe que foi forçado a sair da água para respirar. Ela finalmente encontra seu fôlego criativo em uma mansão

Dicionário Robert.

II

MARLEAU-PONTY, M. L'œil et l'esprit, Paris, Gallimard, 1973, p. 70-71. em uma ilha, de frente para o Mediterrâneo. $O$ mar enfim reencontrado banha a tela de cinema por inteiro, e se torna essa água salvadora, purificadora, mas enquadrada, desabilitando a ameaça de asfixia.

Filmei as nadadoras sem que soubessem, uma de maiô preto até os joelhos (que na saída vestirá o roupão), a outra em duas-peças estampado. A água deveria estar 
inteiramente contida na tela de controle que substitui a janela do quadro de Alberti;as nadadoras permanecem nessa água enquadrada, virtual, modelo reduzido de toda água na qual possamos nos banhar. É como se eu fizesse uma experiência de laboratório filmando as nadadoras imersas num líquido de laboratório cuja substância modificarei mais tarde pela cor, através do computador, seguindo o protocolo de uma rigorosa experimentação, que daria oportunidade à superfície de aflorar sua profundeza nos reflexos. $O$ ponto de vista distante faz a cena recuar no tempo. Desde que as capturo na filmagem, as duas nadadoras estão sob disco rígido da cêmera e presas num passado que recua até o momento em que as águas salgadas submergiram na fenda que formou o Golfo Pérsico. A câmera transfigura a cena em sistema binário. Ele Captura a indiferença matemática da água e das nadadoras, que vejo como prisioneiras da tela, dando voltas sem fim nesse espaço confinado. A água não está na piscina, nem na tela, mas na intimidade cósmica do universo ao qual o numérico dá acesso.

Quando a minha filmadora segue as nadadoras para não deixá-las sair do da água enquadrada pela tela, penso nos assassinatos em piscinas, no cinema: Les Diaboliques (1955), La Piscine (1968), a série de James Bond (1962-2008), nos afogados do Titanic (1997), e sobretudo àqueles que tentam nadar e se salvar no afresco do Dilúvio, do convento da igreja Santa Maria Novella em Florença' ${ }^{12}$. Afresco danificado neste claustro que se abre para um pequeno jardim, que fui ver, com a garganta apertada: para mim, o verdadeiro dilúvio está lá, é em pintura que ele existe, neste fresco desvanecido e parcialmente apagado, aberto a todos os ventos há quase cinco séculos. Na linhagem desses filmes recuando até esse afresco, a câmera captura a junção do ser vivo ao meio onde o drama da existência se encena. No ser humano, observa Dagognet, que filósofo e médico, "o interior e o exterior permitem o fora do antigo dentro" ${ }^{13}$. $\mathrm{Na}$ realidade o ser humano já não se encontra protegido pelos ossos ou seus equivalentes que envolveriam o corpo na origem da vida. Eu me coloco absolutamente do lado dessa fragilidade. É isso que quero magníficar assim como no afresco do Dilúvio, para que possa emergir uma precariedade compartilhada desde essa época.

Será preciso capturar no estado nascente, assim como quando se formou essa ilha onde estou, o fosso entre a realidade concreta e a potência da transfiguração. Isso ficará ao encargo dos cálculos feitos pelo computador, as camadas de cores, que alteram profundamente a definição das imagens, fazendo-as recuar para épocas longínquas em que não se contavam em milhões, os pixels. Tornando-os, simultaneamente, pintura: meio cromossômico em espelho de nossos corpos, mancha em movimento, estígma que se ativa sobre o vivo.

A captura digital, tão bem nomeada, exila as nadadoras dos olhos do espírito assim como daqueles de seus corpos "submetendo sua aparência à força inerente à distância"|'. Enquanto dados matemáticos, elas são traduzidas em esquemas idênticos às estruturas mentais humanas. As nadadoras e a água se metamorfoseiam em
12

Paolo Ucello, Les scènes de la vie de Noé: Le Déluge et le Retrait des eaux, XVe siècle, $206 \times 170 \mathrm{~cm}$, Chiostro Verde, Santa Maria Novella, Florence.

13

DAGOGNET, F. Philosophie d'un retournement, Fougères, Encre marine, 2001, p. 33.

14 ARENDT, H. Condition de l'homme moderne (1961), trad. G. Fradier, préf. P. Ricœur, Paris, Calmann-Lévy, 1994, p. 335-338. 

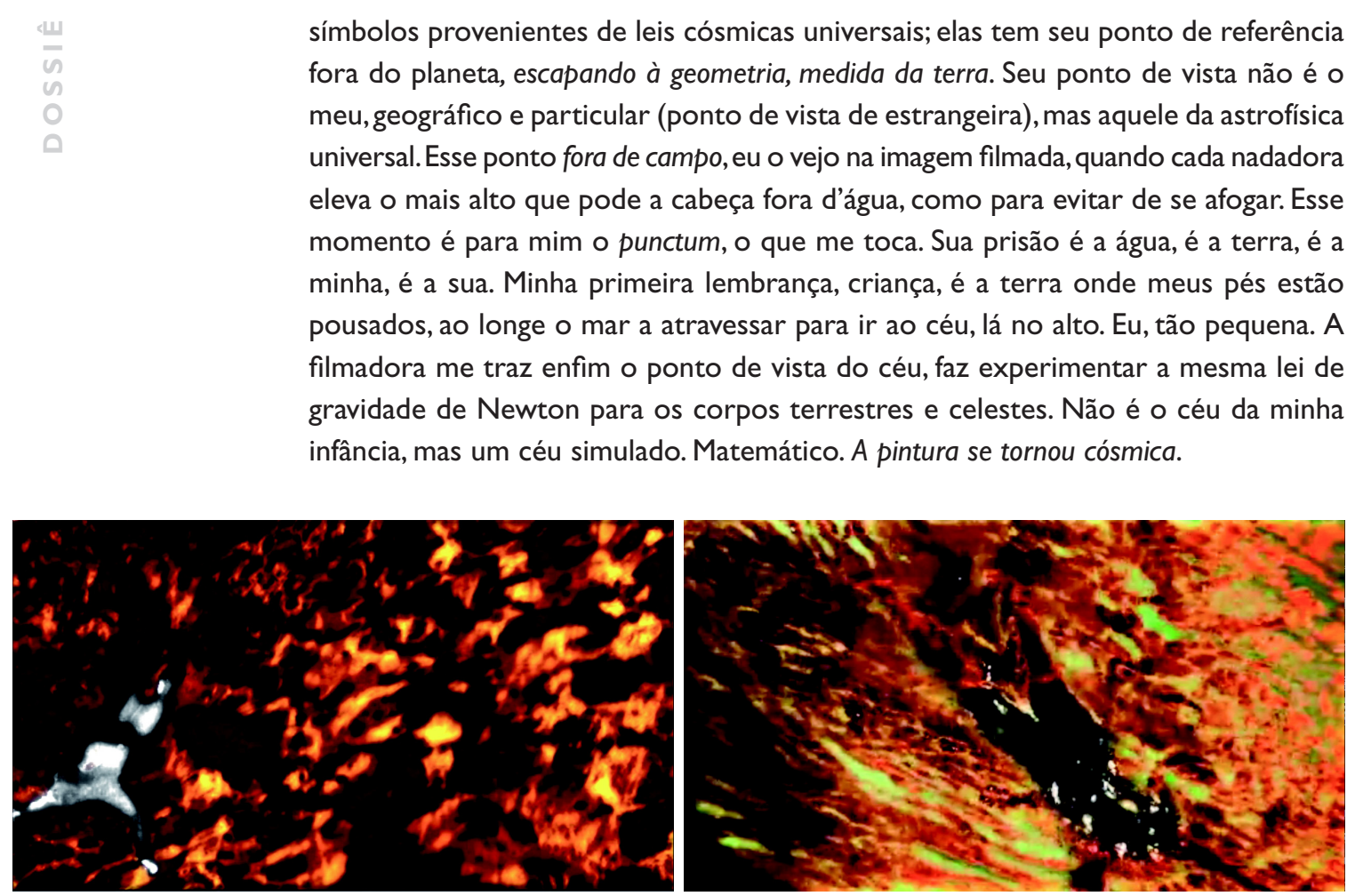

Éliane Chiron.

Les Nageuses I, vídeo digital, 2' 24, 201 I.

\section{Mutações do íntimo na pintura}

15

http://www.lacan.com/symptom8_articles/wajcman8.html. Consulta em |9-10-20||.

16

ARASSE, D. Le sujet dans le tableau, Paris, Flammarion, 2010, p. II.
Foi no Renascimento, séc. XV, que o íntimo foi concebido e pensado na pintura, com a instauração do quadro moderno, definido por Alberti como "janela aberta" para o mundo. Dando a isso uma maior amplitude, G.Wajman "concebe que o quadro moderno terá instaurado, por um mesmo gesto, a idéia cartesiana que o homem tem direito, a partir de então, de olhar para o mundo com Deus, e define o íntimo como o lugar no mundo onde o homem pode se manter separado do mundo, onde, pela janela, em segredo, pode contemplar e através da qual, à exceção de todo olhar pode olhar para si mesmo"'I5. É nessa época que a pintura se torna uma arte liberal pela introdução da matemática, graças ao uso da perspectiva. Pela janela albertiana que permite uma vista, o mundo é representado segundo as leis da perspectiva "legítima", oriunda da geometria, por definição medida da terra. A fim de explorar a invenção do íntimo no quadro, no Renascimento, Daniel Arasse lembra esta idéia de Brunelleschi: "todo pintor se pinta" ${ }^{6}$. Savonarole precisa: "enquanto pintura", “segundo seu conceito". Fórmula em voga em Florença, por volta de 1500. Como o 
íntimo na pintura se metamorfoseia pelo uso do computador, num mundo não mais representado, mas simulado pelo digital? Onde o visor da câmera substitui a janela de Alberti? Segundo que processo o vídeo digital Les Nageuses ${ }^{17}$ (20l0-20II) faz menção à potência infiltrada pela ciência contemporânea e revela nas suas cores as permutações entre carne e sangue, e entre as forças telúricas e o fogo magmático?

Blanchot recusava a "intimidade fechada", esse "mau interior" que nos exclui do acesso verdadeiro às coisas. Ele quer atingir esse ponto que Barthes nomeará punctum e designará como ferida íntima, carnal, que está na obra e no entanto fora de campo. A cor é a cicatriz, ela se pinta sobre a face dos observadores, graças aos neurônios espelhos, descobertos em 1996 pelo neurologista Rizzolatti. No intervalo dessa transferência, acontece esse ponto de origem da obra:"ao mesmo tempo íntimo e exterior, uma intimidade que, em nós, será a realidade do que está fora tal como estaríamos no exterior dessa intimidade e amplidão íntima desse fora"18.

No vídeo, quero que elas nadem no interior de seus próprios corpos e no exterior deles, nessa íntima reversibilidade do vivo (Dagognet). Elas se deslocam como no universo onde só encontramos a nós mesmos e nada vemos além do que se reduz aos esquemas que o ser humano trás em si. Ao inverso da ciência, não há progresso na arte, aos símbolos matemáticos os mitos se superpõem como outras construções do espírito. As nadadoras se deslocam inicialmente numa bacia vermelho vivo, no seu próprio sangue, dando a impressão de dar nascimento à cor, pelos seus movimentos, fazendo a transfusão do vermelho vivo na saída de sua prisão das veias e da carne. O processo geral também é a permanência de uma memória fetal, que é mais viva nos artistas. Num mito dogon* se diz que durante o último mês o feto nada no ventre de sua mãe ${ }^{19}$. Les Nageuses estão nascendo de seu próprio sangue, que se diz impuro para as mulheres, como o artista que nasce de sua obra? No decorrer do trabalho, o vídeo inverte a função de purificação das piscinas nas centrais nucleares, onde se efetua a desativação das impurezas, de onde o som, metálico e surdo, poderia vir. A lentidão e o som transmutam Les Nageuses em corpos-máquinas, imergindo-as em líquidos espessos: sangue, veios de petróleo, abismos púrpuros, lavas em fusão que consomem a nadadora, na penúltima seqüência. Então, Les Nageuses entra na intimidade de uma "morte partilhada, arquetípica, que ressoa no espaço inteiro"20.

Sangue, petróleo, lava, reconhecíveis por suas cores, não são representados, mas simulados. Do tratamento numérico advém uma sombria histologia do corpo fusão do código digital e do código genético, proveniente das grandes fossas abissais onde um dia nasceu a vida. Para os pixels visíveis de perto nos últimos segundos (versão de 20l I) Les Nageuses são fabricadas, derivadas, como Pandora. Assim os ricos panejamentos numéricos com os quais poderiam estar vestidas simulam as movimentações de nossos tecidos e líquidos fisiológicos no brilho da substância profunda da noite cósmica. Exposto em um espaço de arte no Marais, em Paris ${ }^{21}$,
17

Les Nageuses, vidéos numériques, 6'50", 2010 et 2'21, 2011 .

18

BLANCHOT, M. L'Espace littéraire, Paris, Gallimard, coll. Folio Essais, 1955, p. 173.

Os dogons são um povo que vive em uma remota região no interior da Africa Ocidental, em Mali e Bukina Faso. N.T.

\section{9}

DURAND, G. Les Structures anthropologiques de l'imaginaire, Paris, Dunod, 1969, p. 247.

20

Ibid., p. 253.

21

Le Dressing, Espace d'art Free'P'Star, Ier-3I mai 2010, noite e dia. 
22

WILDE, Oscar. De profondis. La Ballade de la geôle de Reading (Librairie générale française, 2000, 1905 et 1962 pour De profondis; 1898 pour La Ballade), precedido de l'Artiste en prison d'A. Camus, trad. et préf. L. Lack et J. Besson, Paris, Le Livre de Poche, coll. Classique, 2004, p. 213.

Éliane Chiron.

Les Nageuses I, vídeo digital, 2' 24, 201 I.
Les Nagueses faz aparecer a cidade mais intensamente na dissipação da noite e das cores num regime noturno de imagens, entrelaçada com a rua sua história sangrenta sob o antigo regime da revolução, o rio que carregou os corpos de algerianos em 17 de outubro de 196I - eu me lembro - que Merleau Ponty nomeia "a carne do mundo". Noturno, oceânico, cósmico, anti-diluviano, ele cintila nas origens da vida confundida com a arte.

O vídeo digital cumpriria a cintilação de nossa alteridade indiferenciada, ou a poiética encontrada no caminho do sangue de uma linhagem artística, de uma genealogia mítica e de uma carne cósmica. Se encarnando em outros corpos o artista desce na paisagem líquida como o sangue nas veias, incorpora a paisagem virtual onde seu corpo não encontra lugar, "o céu que foge/ Através de um cubo de gelo" (le ciel qui fuit I À travers un carré de glace) 22, que olhou Reading "com paixão", o condenado à morte celebrado por Oscar Wilde em Ballade de la geôle de Reading. Mas em Les Nageuses, época em que pela primeira vez a cor púrpura é simulada por cálculos, o céu torna-se científico? O que não anula os poderes peremptórios da arte. O vídeo Les Nageuses exposto pela primeira vez em 2010, pouco antes da erupção de Eyjafjöll, na Islândia, da fuga do petróleo no Golfo do México, dos incêndios da Rússia e das inundações no Paquistão, anunciam a tragédia de Fukushima. Reelaborado posteriormente em $201 \mathrm{I}$, torna-se profecia, revelando fora de contexto, as trevas contemporâneas sob as ameaças que rondam nossos corpos. As nadadoras fazem transfusões entre elas mesmas, na velocidade da luz de seus pixels, não pelas lembranças privadas da infância, nem as cenas públicas da história, mas pelo que Rilke nomeia "intimidade do coração": intimidade de uma anamnése magmática, da noite cósmica e da profundidade oceânica

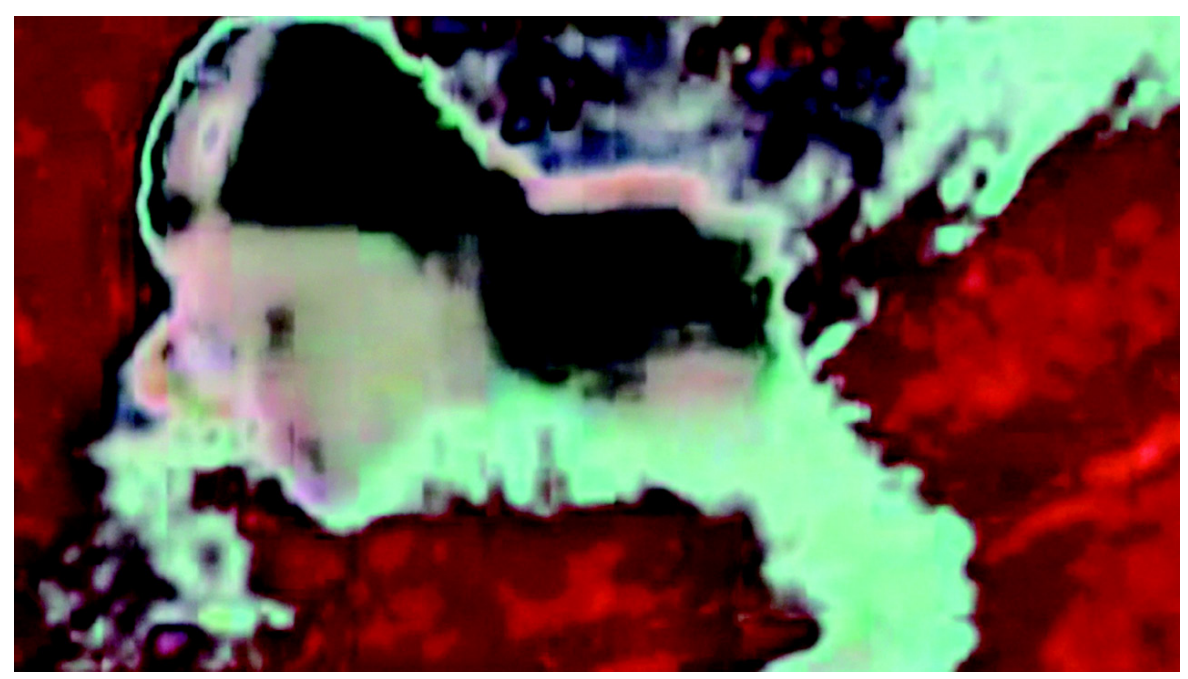


comum a todas as artes. Esta profundidade não está na piscina, mas nas cores do vídeo e de sua transmutação em nós. Nos nossos cromossomas e no nosso DNA que é comum a todos em $99 \%$.

Só a arte, que procura na carne e no sangue a indiferença dos gêneros e das épocas, se levanta, como queria Mallarmé, à potência do céu estrelado que contém, virtualmente, a multiplicidade das galáxias cada vez mais antigas que os telescópios mais e mais gigantes permitem aproximar, com exceção da "matéria negra"* indetectável pela astrofísica. Compondo $95 \%$ do universo, só pode ser simulada digitalmente. Com o digital mesmo a simulação das cores da carne e do sangue se extraem de leis cósmicas que ultrapassam o sistema solar. Distintas das leis planetárias e naturais, elas transfiguram duravelmente dor e precariedade revelado-os no ritmo vivo do colorido. Digital ou não, a arte abriria com essa matéria negra, ou massa ausente do universo, rica de todos os tons ocultos do obscuro, incalculável. Essa matéria negra, como os pretos de Malevich ou de Matisse, é a cor do oculto na carne. É o que permite a encarnação demonstrada pela neurociências. Em nossos cérebro, os neurônios-espelho provocam, através de nosso olhar, o esboço do gesto - aqui das nadadoras fazendo surgir em círculos, do negro, suas cores, a cada volta que dura 2 minutos e 21 segundos. Então, se o vídeo pode ser projetado ao contrário numa grande tela, com um som de máquina ressoando como em um grande canteiro telúrico, espécie de inferno, devemos sentir a sensação de estar no meio da cor se produzindo num ensurdecedor ruído. Na cor como meio, enfim, desvinculada de um fundo, assim como Benjamin definiu.

O que mostra, como toda arte, esse vídeo-pintura? O desaparecimento dos seres e das coisas na intimidade de suas mortes, sua encarnação virtual e real, ao mesmo tempo. É por isso que assim como a matéria negra que nomeamos massa oculta, quando a obra se mostra ao público, essa intimidade deve permanecer disfarçada. Em latência, escondida no sensível.Virtual. Inacessível. Sagrada. É essa "intimidade do coração" sendo o coração um órgão que "pensa" ${ }^{23}$ por primeiro, ativado por uma região particular do cérebro. $O$ íntimo na arte só existe encarnado, mas só se encarna no olhar do público. A arte não tem nada a ver com as memórias da vida privada ou com as circunstâncias da vida social, só com a vida interior da arte, de gesto em gesto, com meios renovados a cada época, sem que os meios tradicionais se tornem obsoletos, uma vez que não há progresso na arte. Convém, no entanto, de qualquer maneira e sem descanso, retornar às origens, ao que é chamado, nos mitos, "antes do Dilúvio", que provoca o artista e o faz mergulhar.Vítima e carrasco.

"Na vida real (diz Louise Bourgeois), eu me identifico com a vítima, por isso me voltei para a arte. $\mathrm{Na}$ minha arte eu sou o assassino. Eu simpatizo com a situação do assassino" ${ }^{24}$. Em Les nageuses, é através da cor pictórica que eu assassino, incinerando uma delas na lava fervente. A projeção da piscina é o "quadro perfeito", como
A matéria escura, ou matéria negra, não pode ser vista por astrônomos com telescópios. Ela não emite nem reflete luz, por isso, não brilha como uma estrela. Basicamente, a matéria escura não pode ser vista - os cientistas conseguem apenas imaginar onde ela está com base nos efeitos gravitacionais do que eles podem ver. http://ciencia.hsw.uol.com.br/ materia-negra.htm. N.T.

\section{3}

CASSIRER, E. Langage et mythe. $\dot{A}$ propos des noms de dieux (1924), trad. 0. Hanse-Love, Paris, Minuit, 1973, p. 63-64.

\section{4}

Louise Bourgeois: sculptures, environnements, dessins 1938-1995, Paris, Musée d'art moderne de la ville de Paris, 1995, p. 49. 


\section{5}

David Hockney, Portrait d'un artiste (Piscine avec deux figures), 1972, acrilico sobre tela, $214 \times 305 \mathrm{~cm}$, col. particular.

\section{6}

David Hockney. Espace-paysage, catálogo de exposição, Paris, Centro Georges Pompidou, 1999, p. 96.

27

Ibid., p. 196.

28

MARLEAU-PONTY, M. L'œil et l'esprit, Paris, Gallimard, 1973, p. 70-71.

29

Gregory nageant. Los Angeles, ${ }^{e}$ mars 1982, montagem com polaroïd, $70,5 \times 130,2 \mathrm{~cm}$, coll. D. Hockney.

30

Hockney, op. cit., p. 197.

31

LYOTARD, op. cit., p. 163.

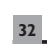

lbid. dizemos em David Hockney? Em Portrait of Artist (Piscina com duas figuras) 1972”"25 "0 personagem na piscina torna-se uma alegoria da figura pintada, e a piscina, o símbolo da arte" 26 . Sim, mas podemos ver no quadro de Hockney uma cena de assassinato, onde o nadador é um afogado cujo assassino está em pé na beira da piscina, com um casaco vermelho, verificando com o olhar que ele não se move. $O$ artista estaria supostamente desdobrado em duas figuras. Devemos, diz ele, "sentir-se e pintar: de alguma forma, sair de nós mesmos e se colocar na pintura. [...] Eu sempre fui obcecado pelo fato de ver [...]As artes visuais devem tratar do ver porque a primeira coisa que se espera das artes visuais é olhar" ${ }^{27}$. Testemunhar o crime perfeito? No final do século XV, para Marsile Ficin, o filho de um médico, "as obras de arte que remetem à visão e à audição proclamam o espírito do artista”, quer dizer, a "disposição" e "a imagem de sua mente", porque "o espírito se expressa e reflete como em um espelho”. Espelho, não é de estranhar que a piscina seja o paradigma que MerleauPonty fornece a descrição:"Quando eu vejo através da espessura da água, os azulejos no fundo da piscina, eu não vejo apesar da água, dos reflexões, vejo justamente através deles, por meio deles. [...] Se eu visse sem essa encarnação a geometria dos azulejos, eu cessaria de os ver como são e onde estão, isto é: além de todo lugar idêntico"28. Hockney diz ainda sobre outra de suas piscinas: Gregory nadando. Los Angeles, 0 I de março de $1982^{29}$, que ele imagina "como sendo [sua] versão dos tetos de Tiepolo [...] você sabe, esses arcos barrocos cobertos de anjinhos rechonchudos que se erguem bem alto no céu tão azul"30.

\section{A íntima mutabilidade da matéria pictórica}

Em L'inhumain, Lyotard, que sabia olhar uma pintura, escreveu: "o pintor se deixa apreender e alienar por um matiz" ${ }^{31}$. Ele tomava como exemplo, Cézanne, que diante da montanha [...] queria que essa alienação, o observador também pudesse experimentar [...] através da cor depositada e composta no quadro. "E quando eu digo cor [acrescentava Lyotard], isso se entende como sendo toda matéria pictórica". De modo inverso a Cézanne diante da montanha, é no cinema e mais freqüentemente na televisão que erupções vulcânicas e tsunamis, catástrofes de todas as espécies, penetraram em imagens provocadas pelos neurônios-espelhos, no íntimo "do que se vê em mim" (Merleau-Ponty). Eu quis atribuir a esses neurônios-espelhos, imateriais e luminosos, bem reais para mim, sua íntima materialidade pictórica, cromossômica, através da mutabilidade da cor "que a torna propícia ao desarmamento do olhar"32, na "derrota do espírito". Condições de um devir mucoso, órgãos, palpitar do coração, vísceras. E com isso que, definitivamente, pintamos. As mutações de uma piscina e das nadadoras não são apenas uma desculpa para experimentar a mutabilidade íntima da material digital. 
Foi por acaso que filmei em 2008, em Baheïn, esse país do Golfo que foi sacudido, três anos mais tarde, como os outros, pela "primavera árabe"? Será que vi nas duas nadadoras cuja diferença de origem me tocaram, a violência do conflito que aconteceria? Conflito sobre o qual caiu um muro de silêncio. $O$ que eu vi, não foi o azul de uma piscina de um hotel de luxo para turistas afortunados, mas sua parte obscura, sua tragédia latente. Como um chamado. Da mesma forma que Hockney, que foi designer gráfico ${ }^{33}$ e durante muito tempo fez experimentações com computador e impressoras a cores, expulsou o azul das piscinas californianas e do céu dos tetos barrocos para dar lugar a esse vermelho vivo de que são pintadas as imensas telas do Grand Canyon $^{34}$, chagas vivas a céu aberto. Sob a fina tira de céu azul que corre nas $744.2 \mathrm{~cm}$ de comprimento do Bigger Grand Canyon, vemos sua carne vomitada pelas bocas abertas de um par de condenados, em um duplo grito erétil.

As condições de ser contemporâneo? "Não se deixar cegar pelas luzes do século e [conseguir] captar nelas a parte obscura, sua sombra intima" ${ }^{35}$. Tem de entrar na pintura sem temer o risco de se aí perder, seja ela produzida por um código, ou pelo contato íntimo com o pictórico, uma vez que é preciso desaparecer na pintura assim como o pintor chinês na paisagem. Tornar-se como a nadadora que se afoga nos pixels, boca aberta, e renasce do seu sangue. "Entre o mundo e eu, escolher o mundo", disse Kafka. Dar surgimento a um mundo em pintura, mesmo que por meio do vídeo digital. Hockney, impressionado com uma exposição de Picasso na Galeria Tate, diz: "Ele poderia dominar todos os estilos, todas as técnicas. A lição que posso tirar é que devemos utilizar todos os meios”. Maneira de retornar, a cada vez, às origens genealógicas da arte, a um campo expandido da pintura, o verdadeiro corpo da artista. Maneira, assim como Louise Bourgeois, de "escolher a arte sobre a vida".

\section{3}

Ele obtém, em Bradford, o National Diploma of Design e produziu cenários de opéras e cartazes.

\section{4}

A Bigger Grand Canyon, 1998, huile sur 60 toiles, $207 \times 744 \mathrm{~cm}$, coll. D. Hockney.

\section{5}

AGAMBEN, G. Qu'est ce que le contemporain?, trad. M. Rovere, Paris, Payot et Rivages, coll. Poche, 2008, p. 21.

26 de Outubro 2011

\section{REFERÊNCIAS}

AGAMBEN, G. Qu'est ce que le contemporain ?, trad. M. Rovere, Paris, Payot et Rivages, coll. Poche, 2008. ARASSE, D. Le sujet dans le tableau. Essais d'iconographie analytique (1997), Paris, Flammarion, 4è édition 2010.

ARENDT, H. Condition de l'homme moderne (196I), trad. G. Fradier, préf. P. Ricœur, Paris, CalmannLévy, 1994.

CASSIRER, E. Langage et mythe. À propos des noms de dieux (1924), trad. O. Hanse-Love, Paris, Minuit, 1973.

BAZAINE, J. Le temps de la peinture (1938-1989), Paris,Aubier, 1990. 
BLANCHOT, M. L'Espace littéraire, Paris, Gallimard, coll. Folio Essais, 1955, p. 173.

BENJAMIN,Walter. Peinture et graphisme. De la peinture ou le signe et la marque (Surkamp Verlag, Frankfurt am Main, 1977), trad. P. Pénisson, La part de l'œil, dossier Le dessin, 6, 1990, pp. I3-15. Écrits français, prés. et intr. J.M. Monnoyer, Paris, Gallimard, 1991.

CENNINI, Cennino. Le livre de l'art ou traité de la peinture(entre 1390 et I437), descoberto pela primeira vez por chevallier Tambroni, trad.V. Mottez (I858), nouv. éd. augm. Paris, F. de Nobele, 1978 DAGOGNET, F. Philosophie d'un retournement, Fougères, Encre marine, $200 \mathrm{I}$.

DURAND, G. Les Structures anthropologiques de l'imaginaire, Paris, Dunod, 1969.

LACAN, J. Le séminaire. Livre XI. Les quatre concepts fondamentaux de la psychanalyse (1964), Paris, Seuil, 1973.

LYOTARD, J. F. L'inhumain. Causeries sur le temps, Paris, Galilée, 1988.

MERLEAU-PONTY, M. L'œil et l'esprit, Paris, Gallimard, 1973.

WILDE, Oscar. De profondis. La Ballade de la geôle de Reading (Librairie générale française, 2000, 1905 et 1962 pour De profondis; 1898 pour La Ballade), precedido de L'Artiste en prison d'A. Camus, trad. et préf. L. Lack et J. Besson, Paris, Le Livre de Poche, coll. Classique, 2004.

\section{ÉLIANE CHIRON}

Artista Plástica, Professora Emérita na Universidade de Paris I, Panthéon-Sorbonne onde defendeu tese de Estado. Dirige, na Universidade de Paris I, o Centro de Pesquisas em Artes Visuais (CRAV). Sua pesquisa, em cruzamento com a prática artística, interroga o processo de criação e as mutações do olhar, principalmente em relação ao digital. Publica e expõe em diversos paises (Brasil, China, Tunisia, Coréia, etc.). Editou em Publications de la Sorbonne, uma série de obras: X, l'œuvre en procés : Croisements dans l'art (1996), Croisements des arts (1997), L'incertain dans l'art (1998), La main en procès dans les arts plastiques (2000), L'objet et son lieu (2004). Paysages croisés. La part du corps (2008), Migrations / Mutations. Paysages dans l'art contemporain (2010), L'intime, le privé, le public dans l'art contemporain (2012). No prelo: L'énigme du visible. 